\title{
COMMENTARY
}

\section{SAVE DARFUR: A MOVEMENT AND ITS DISCONTENTS}

\author{
DAVID LANZ
}

'Save Darfur', arguably the largest international social movement since antiapartheid, has had an important impact in shaping the international response to the Darfur conflict: the world's largest humanitarian operation, alongside one of the largest and most expensive peacekeeping missions and a plethora of special envoys and mediators. For the first time, the US government has declared an ongoing conflict to be genocide and permitted the UN Security Council to refer a case to the International Criminal Court (ICC). In spite of these achievements (and indeed because of them), the Save Darfur movement has been widely criticized, most publicly by Mahmood Mamdani in his recent Saviours and Survivors. ${ }^{1}$

This commentary reviews the factors that led to the emergence of the Save Darfur movement ${ }^{2}$ before considering its achievements, and assessing critiques including Mamdani's claim that Save Darfur constitutes the 'humanitarian face of the War on Terror' and is therefore 'a slogan that masks a big power agenda to recolonize Africa'. ${ }^{3}$ While pointing to some of the blind spots of advocacy efforts, Mamdani's grandstanding arguments about the nature of the movement are not fully convincing. Rather than a neo-colonial project, Save Darfur is better understood as a platform through which norm

David Lanz (david.lanz@swisspeace.ch) is a doctoral student with the Swiss Peace Foundation, swisspeace, and the University of Basel. The author is grateful for the useful feedback provided by participants in a seminar at the European Conference on African Studies (ECAS) in Leipzig in 2009, where an earlier draft of this commentary was presented. He also thanks the editors of African Affairs and Medina Haeri for their helpful comments, although the opinions expressed are solely the responsibility of the author. Research for this article was supported by the Doctoral Programme on 'Global Change, Innovation and Sustainable Development' funded by the Swiss National Science Foundation (SNSF).

1. Mahmood Mamdani, Saviours and Survivors: Darfur, politics, and the War on Terror (Verso, London, 2009).

2. Throughout the text, 'Save Darfur' refers to the multitude of organizations that work to raise awareness about and bring an end to what they consider the genocide in Darfur. Many, but not all of these organizations are part of the official 'Save Darfur Coalition', founded in July 2004 in New York to coordinate Darfur advocacy efforts. See the website of the Save Darfur Coalition, <http://www.savedarfur.org/> (all websites cited in this article were accessed on 13 July 2009).

3. Mamdani, Saviours and Survivors, pp. 6, 300. 
entrepreneurs have promoted their ideas of global governance, revealing the perils of blindly projecting liberal norms on a complicated world.

Darfur has become the test case of the 'responsibility to protect' - R2P doctrine, the idea that the 'international community' has a duty to intervene to prevent and stop mass atrocities. ${ }^{4} \mathrm{R} 2 \mathrm{P}$ is an ambitious plan for a new world order in which sovereignty is no longer an argument against external intervention for humanitarian purposes. It follows that the international response to the Darfur conflict has been more concerned with the global project to promote $\mathrm{R} 2 \mathrm{P}$ than with the local realities of Darfur and the imperative of peacemaking on the ground. This does not, however, mean that Save Darfur and the so-called 'international community' - which is really an amalgam of Western powers and non-governmental groups who share a diffuse ideology based on liberal values - want to project power and take control of Sudan, or Africa for that matter. Rather, it seeks to project norms and promote a world order in which values trump power. While the consequences may be equally problematic, the motivation is different.

\section{Founding Save Darfur}

Save Darfur emerged as a movement in the summer of 2004, more than one year after the conflict in Darfur reached a point of no return. Within a few months, Save Darfur became very influential within the US, which begs the question of why a strategically unimportant region in Africa has become a foremost foreign policy issue. I argue that the Save Darfur movement benefited from four factors: a compelling cause, a favourable domestic political context, determined and savvy leadership, and significant movement magnifiers. First, the narrative that advocates have created is of Darfur as a place of good and evil, victims and perpetrators, villains and heroes: the evil Sudanese government mobilized vicious 'Arab' tribal militias and induced them to commit genocide against innocent 'African' victims. The heroes of this tragedy are Western aid workers, human rights activists, and the advocates themselves who courageously save lives and speak out against the atrocities. The forces of evil still run havoc and in order to save the victims, who have little agency of their own, Western military intervention is needed. This description is a caricature, but it captures the essence of the activists' framing of the Darfur conflict. ${ }^{5}$ As a cause therefore, Darfur was

4. For the state of the art of the doctrine, see a recent book by one of the principle architects of R2P: Gareth Evans, The Responsibility to Protect: Ending mass atrocity crimes once and for all (Brookings Institution, Washington, DC, 2008). For the application of R2P in the context of Darfur, see Nick Grono, 'Briefing - The international community's failure to protect', African Affairs 105, 421 (2006), pp. 621-31.

5. See Deborah Murphy, 'Narrating Darfur: Darfur in the US press, March-September 2004' in Alex de Waal (ed.), War in Darfur and the Search for Peace (Harvard University Press, Cambridge, MA, 2007), pp. 314-36. 
both easy to sell and also unthreatening for the political establishment. Second, the Darfur advocacy campaign gained momentum during an electoral year and at a time when the US faced a severe crisis of legitimacy as a result of the invasion of Iraq in 2003. Darfur provided an opportunity for liberals, who had supported the war in Iraq for humanitarian reasons, ${ }^{6}$ to reclaim the moral high ground. Save Darfur therefore met a political context that received its activities favourably.

Third, the leaders of the Save Darfur movement operated very skilfully, maximizing the impact of their work through coalition building. They created a movement, whose cause was sufficiently vague and non-menacing to allow it to become a catch-all for various civil society groups. They managed to tap into traditional Christian advocacy for Sudan, Jewish preoccupation with genocide, human rights groups' support for international criminal justice, the conflict resolution community's enthusiasm for R2P, student idealism, and the philanthropic impulse of celebrities. Finally, the Save Darfur movement was magnified by technology and an efficient management model. Internet sites and e-mail lists were Save Darfur's primary mobilizing tools, allowing for a highly efficient use of resources. Students proved particularly adept in this regard. ${ }^{7}$ Equally conducive was the decentralized management of the movement: apart from a loose association within the Save Darfur Coalition, there are no central coordinating structures, allowing for maximum flexibility as well as pragmatic adaptation of the cause to the concerns of particular constituencies. The Save Darfur movement emerged in the US, but later spread and gained significant momentum in Europe, in particular France and the UK.

\section{Taking stock of Save Darfur's achievements}

The persistent lobbying of the Save Darfur movement has led governments and international organizations to react to the crisis in ways that go beyond typical policy responses to conflicts in Africa. In what follows, I consider different dimension of the response to the Darfur conflict shaped by the Save Darfur movement: rhetorical, political, military, legal, and humanitarian. Manifestly, the movement cannot be credited (or blamed) for all responses. However, Save Darfur has been instrumental in explaining the scale as well as the form of the response to the conflict. Save Darfur has been most successful in affecting the rhetoric of governments, the most spectacular achievement being former US Secretary of State Powell's 2004 determination that the Darfur conflict constituted genocide. Furthermore,

6. See Alan Wolfe, 'Empty nest: the demise of a species', World Affairs (Winter 2009).

7. Rebecca Hamilton and Chad Hazlett, "Not on our watch": the emergence of the American movement for Darfur' in Alex de Waal (ed.), War in Darfur, pp. 337-66, pp. 362-3. 
the US administration has made countless references to Darfur, usually condemning the violence and promising action; such calls were common in countless speeches during the US presidential campaigns in 2004 and 2008. Darfur also became a favoured topic of the French and UK governments, epitomized in President Sarkozy and Prime Minister Brown's joint op-ed in The Times, advertising their commitment 'to save the Darfuris' ${ }^{8}$

Save Darfur not only influenced the rhetoric of policy makers, but accomplished real policy change, in particular in the US. The Sudan Divestment campaign, spearheaded by student activists, was very successful, akin to the anti-apartheid campaign targeting South Africa in the 1980s. Of particular note was the unanimous passage in both houses of the US Congress of the 2007 Sudan Accountability and Divestment Act, which required companies applying for US government contracts to prove that they were not conducting business in Sudan. ${ }^{9}$ The pressure was effective at the executive level as well: in 2007, President Bush announced sanctions against highranking officials of the Sudanese government and companies operating in Sudan. ${ }^{10}$ In Europe, the results were less tangible, but the Darfur advocacy triggered various diplomatic initiatives by European governments seeking to put pressure on the Sudanese government. Save Darfur also targeted China, Sudan's most important international ally. Under the banner of the 'Genocide Olympics', a campaign was mounted to chastise the Chinese government for its political support and economic relations with Sudan. ${ }^{11}$ Though resentful of the moralizing discourse of the West, China nevertheless responded to the campaign pressure with some policy changes, notably appointing a special envoy and dropping its initial resistance to a robust UN peacekeeping mission in Darfur. ${ }^{12}$

From the outset, the Save Darfur movement has advocated for a military intervention to protect civilians in Darfur. Early on, some activists demanded a full-fledged, non-consensual intervention by NATO like that undertaken in Kosovo in $1999,{ }^{13}$ but these claims were soon largely abandoned - a nuance that Mamdani ignores. Instead, Save Darfur advocated the deployment of a large peacekeeping mission to protect civilians

8. Gordon Brown and Nicolas Sarkozy, 'We are pushing and pushing to save the Darfuris', The Times, 31 August 2007, p. 19.

9. For details of the divestment campaign, see an account by two Darfur activists associated with the Enough Project: Colin Thomas-Jensen and Julia Spiegel, 'Activism and Darfur: slowly driving policy change', Fordham International Law fournal 31, 4 (2008), pp. 843-58.

10. Sheryl Gay Stolberg, 'Bush tightens penalties against Sudan', New York Times, 29 May 2007.

11. Helen Cooper, 'Darfur collides with Olympics, and China yields', New York Times, 13 April 2007.

12. Daniel Large, 'China and the contradictions of "non-interference" in Sudan', Review of African Political Economy 35, 115 (2008), pp. 93-106.

13. See, for example, Eric Reeves, 'Regime change in Sudan', Washington Post, 23 August 2004. 
proactively, if necessary by using force. At first, this translated into support for the African Union Mission in Darfur (AMIS). However, starting in 2005 the establishment of a UN peacekeeping mission in Darfur became Save Darfur's most important goal, absorbing much of the movement's energy. A UN mission requires UN Security Council authorization (and therefore veto power acquiescence), which resulted in protracted diplomatic negotiations, culminating in the July 2007 compromise that established the UN-AU joint mission, UNAMID. ${ }^{14}$ At the same time, European countries led by France's activist foreign minister Bernard Kouchner, decided to set up a peacekeeping force - EUFOR - across the border in Eastern Chad. ${ }^{15}$

Another dimension of Save Darfur's achievements pertains to international criminal justice. In March 2005, after intense lobbying to overcome US resistance, the UN Security Council referred the situation in Darfur to the ICC. ${ }^{16}$ Save Darfur was central in this endeavour and it is clear that had it not been for their mobilization, the referral would not have happened. One final achievement of Save Darfur pertains to the humanitarian response in Darfur. With over 10,000 humanitarian workers and one hundred relief agencies, Darfur is home to the world's largest humanitarian operation. ${ }^{17}$ The attention generated by Save Darfur undoubtedly contributes to sustaining this operation.

The international response to the Darfur crisis demonstrates that transnational non-state actors promoting a normative project can play a significant role in international affairs. A careful examination of the underlying concepts and assumptions of the Save Darfur movement reveals three general features of Save Darfur's strategy which deserve attention. First, Save Darfur focuses on external intervention to solve the conflict in Darfur, rather than on domestic processes. This reflects an assumption of R2P, namely that when a certain level of violence is reached, international actors must step in and provide protection to the most vulnerable. There is therefore a tendency to portray people affected by conflict as helpless victims, who need to be saved from the outside - hence the name Save Darfur. What this approach neglects, as Mamdani rightly points out, is the recent experience of Afghanistan and Iraq, where foreign interventions led to protracted crises with high levels of violence. ${ }^{18}$

14. Jair van der Lijn, To Paint the Nile Blue: Factors of success and failure of UNMIS and UNAMID (Clingendael Institute and Radbound University Nijmegen, The Hague, 2008).

15. Björn Seibert, 'African Adventure? Assessing the European Union's military intervention in Chad and the Central African Republic' (MIT Security Studies Program working paper, Boston, November 2007).

16. Zachary Kaufman, 'Justice in jeopardy: accountability for the Darfur atrocities', Criminal Law Forum 16, 3-4 (2005), pp. 343-60.

17. Fabrice Weissman, 'Humanitarian dilemmas in Darfur' (Médecins Sans Frontières working paper, July 2008), <http://www.msf.fr/drive/214a9aa0483c6e560e05cdafb00beb11.pdf > . 18. Mahmood Mamdani, 'The politics of naming: genocide, civil war, insurgency', London Review of Books, 8 March 2007. 
Second, Save Darfur activists generally favour military over political strategies to solve the conflict in Darfur. The lesson they learned from the Rwandan genocide is that delaying intervention or deferring to diplomacy, will leave many dead. ${ }^{19}$ Thus, it is not surprising that peace negotiations between the Sudanese government and the Darfur rebel movements have not been a priority for Darfur activists. They are not opposed to peacemaking, but Save Darfur's strong insistence on intervention can crowd out political conflict resolution strategies. In that sense, Mamdani is right that Save Darfur is not a peace movement, although his claim that Darfur student activists are 'child soldiers' for their support of war is exaggerated. ${ }^{20}$

Third, Save Darfur has opted for confrontational policies targeting the Sudanese government. For most Darfur activists, the Sudanese government bears overwhelming responsibility for armed conflict in Darfur and other parts of Sudan. Indeed, their anti-Khartoum stance connects Darfur activists with Christian groups concerned about Southern Sudan. The strategy of Save Darfur consists of putting diplomatic, economic and moral pressure on the Sudanese government and its allies, especially China, in order to raise the costs of their policies. However, Save Darfur's focus on the Sudanese government tends to neglect the responsibility of other actors, such as rebel movements, former colonial powers, or neighbouring countries. ${ }^{21}$ Also, confrontation may not be the best strategy to change the Sudanese government's policies; engagement and compromise may be more effective, as the North-South peace process demonstrated. ${ }^{22}$

\section{Critiquing Save Darfur}

With influence comes responsibility. As Save Darfur grew as a movement, its activism was increasingly scrutinized. The camp of sweeping critics is led by Mamdani. For him, Save Darfur is a wolf in sheep's clothing, concealing its geopolitical agenda in compelling moral and humanitarian arguments. ${ }^{23}$ Save Darfur is thus a modern version of nineteenth-century colonialism, as European powers invoked a noble mission civilisatrice to justify the subjugation of Africa. A more moderate and convincing critique is marshalled by Alex de Waal: he grants that Save Darfur activists are well-intentioned and that a movement to prevent conflict in Africa is in and of itself a good

19. Darran Brunk, 'Dissecting Darfur: anatomy of a genocide debate', International Relations 28, 1 (2008), pp. 25-44.

20. Mahmood Mamdani, 'Mamdani responds to his critics II', <http://www.ssrc.org/blogs/ darfur/2009/05/12/mamdani-responds-to-his-critics-ii/ $>$.

21. This is a point that Mamdani makes throughout Saviours and Survivors.

22. Alex de Waal, 'Sudan: International dimensions to the state and its crisis' (Occasional Paper No. 3, LSE Crisis States Research Centre, London, April 2007).

23. A similar argument is made by Steven Fake and Kevin Funk, The Scramble for Africa: Darfur, intervention and the US (Black Rose Books, Montreal, 2009). 
thing. However, he maintains that the problem with Save Darfur is their projection of moralistic simplicities without regard for negative side-effects on the ground. ${ }^{24}$

While putting forward different interpretations of the motivation of Save Darfur, critics more or less agree that advocacy efforts do have perverse effects. In what follows, I discuss four key negative effects pertaining to Save Darfur's framing of the Darfur conflict and its remedies. First, Darfur advocates have framed the conflict as a genocide committed by 'Arabs' against 'Africans', implying that the conflict is caused by the cultural incompatibility of these groups. However, the causes of the Darfur conflict are multifaceted and include unequal distribution of land, ecological degradation, Darfur's marginalized place in the Sudanese state and nation, and the destructive influence of regional and international powers. ${ }^{25}$ The Arab vs African narrative brushes over such complexity. Also, the Darfur conflict did not manifest itself as a total ethnic war, as many Arab tribes fought each other or remained neutral - the Southern Rizeigat in South Darfur, for example. ${ }^{26}$ By perpetuating the Arab vs African narrative, Save Darfur has not only simplified a complex conflict, but they may have contributed to entrenching antagonistic identities, as victims have increasingly referred to genocide as a frame for their suffering.

Second, Darfur advocates have framed the conflict by assigning fixed ethnic labels: Arabs are perpetrators, who need to be punished, while Africans are victims in need of protection. ${ }^{27}$ The danger of this narrative is that it fosters neglect of reverse categories, such as 'African perpetrators' and 'Arab victims'. Julie Flint, for example, contends that the voices of Arabs are largely sidelined in the peace process, although their inclusion is crucial to achieving peace in Darfur. ${ }^{28}$ Moreover, it is not so surprising that the crimes committed by non-Arab rebel groups have not generated as much attention as the atrocities authored by the Sudanese government and its fanjaweed allies, although the recent ICC charges against three rebel leaders are encouraging counter-examples. ${ }^{29}$ According to Mamdani, Save Darfur has

24. For more on Alex de Waal's critique of Save Darfur, see his debate with one of the leaders of the Save Darfur movement, John Prendergast: 'Dueling over Darfur', Newsweek, $<$ http://www.newsweek.com/id/69004>.

25. For nuanced, although different accounts of the causes of the war in Darfur, see M. V. Daly, Darfur's Sorrow: A history of destruction and genocide (Cambridge University Press, New York, NY, 2007); Julie Flint and Alex de Waal, Darfur: A new history of a long war (Zed Books, London, 2008); Gérard Prunier, Darfur: A twenty-first century genocide, third edition (Cornell University Press, Ithaca, NY, 2008).

26. Mamdani, Saviours and Survivors, p. 16.

27. Murphy, 'Narrating Darfur', pp. 315-17.

28. Julie Flint, 'Including Darfur's Arabs in the peace process', <http://www.ssrc.org/blogs/ darfur/2009/05/10/including-darfurs-arabs-in-the-peace-process/ $>$.

29. Colum Lynch, 'Rebels charged with war crimes in Sudan', Washington Post, 18 May 2009. 
contributed to demonizing Arabs in Darfur, although paradoxically, Arab marginalization constitutes one of the historic root causes of the conflict.

Third, Save Darfur's insistence on humanitarian intervention has distorted the expectations of Darfur rebel movements. During the Abuja peace negotiations it fostered maximalist positions, allowing the rebels to hide behind the prospect of foreign military intervention, without seriously working on a political settlement. Abdelwahid al-Nur, for example, alluding to NATO's intervention in the Balkans, told the mediators that he would only sign a peace agreement if he got 'a guarantee for implementation like in Bosnia' ${ }^{30}$ The insistence of advocacy groups on peace enforcement has likewise made the deployment of a UN peacekeeping force the first priority of the US and other states. ${ }^{31}$ This in turn led to the use of 'deadline diplomacy' to bring the Abuja talks to a premature end, depriving the parties of their ownership of the process and producing a peace agreement that lacked popular support and failed to be signed by all rebel factions. ${ }^{32}$

Finally, Darfur advocates have contributed to the de-politicization of conflict intervention by fostering a simplified understanding of armed conflict in Africa as a story of evil villains and heroic saviours, of innocent victims and guilty perpetrators. Armed conflict is no longer the outcome of social processes growing out of a complex history, but rather a stage for the projection of evil. External interventions to 'manage' conflict thus become virtuous efforts to fight evil, instead of politically motivated and potentially problematic intrusions. Julie Flint eloquently remarked about Darfur advocates: 'For them, Darfur is not a place with a complex history; it's a moral high ground. ${ }^{33}$

\section{Conclusion: making sense of Save Darfur}

The biggest predicament of the Save Darfur movement is its disconnection with the realities on the ground. Save Darfur emerged as a movement in late 2004, promising to stop genocide at a time when the violence was diminishing and the humanitarian situation in Darfur was stabilizing. Their projection of 'an outdated script' ${ }^{34}$ on a complex reality has had negative side-effects, the most important of which was the international community's lack of focus on peace negotiations. Nevertheless, Mamdani's assertion that Save Darfur is a project to re-colonize Africa and demonize Arabs does

30. Quoted in Alex de Waal, 'I will not sign', London Review of Books, 30 November 2006.

31. Alex de Waal, 'Darfur and the failure of the responsibility to protect', International Affairs 83, 6 (2007), pp. 1039-54.

32. Laurie Nathan, 'No ownership, no peace: the Darfur peace agreement' (Working Paper

No. 5, LSE Crisis States Research Centre, London, September 2006).

33. Julie Flint, 'Darfur, saving itself', Washington Post, 3 June 2007.

34. Julie Flint, 'In Sudan, help comes from above', New York Times, 6 July 2007. 
not seem plausible. Activists are generally critical of the US government, denouncing in particular its collaboration with the Sudanese government in anti-terrorist matters. Moreover, the Save Darfur movement consists of many groups that have been overwhelmingly critical of US policy in the Middle East, including the war in Iraq, in particular NGOs based in Europe. A few right-wing Bush-supporters are not enough to turn a movement into a US government vanguard.

As a test case for the emerging norm of the responsibility to protect, Darfur exemplifies the perils of blindly projecting liberal norms on a complicated world. Its premise is that in the face of large-scale atrocities, passivism is tantamount to moral bankruptcy and that action is required to prevent and stop large-scale violence. The challenge is, in the words of Samantha Power, to transform people from 'bystanders' in the face of genocide (as in Rwanda) to 'upstanders' mobilizing for intervention to stop genocide. ${ }^{35}$ Many Save Darfur advocates see themselves as part of a bigger project: to build a permanent constituency to end crimes against humanity and genocide. In that sense, Darfur is more about 'us' than about 'them'; it is more about promoting liberal norms pertaining to $\mathrm{R} 2 \mathrm{P}$ than about actually ending the conflict and making peace in Darfur. Self-interest is not as such Save Darfur's predicament. However, their projection of a 'humanitarian fundamentalism' and 'conflict response by analogy' ignores realities on the ground. What seems to be most lacking from the Save Darfur repertoire is a pragmatic assessment of their actions in order to prevent good intentions from doing harm. ${ }^{36}$

35. See Samantha Power, A Problem from Hell: America and the age of genocide (Basic Books, New York, NY, 2002).

36. For an argument to apply the 'Do No Harm' approach arising from humanitarian aid to Darfur advocacy, see Medina Haeri, 'Saving Darfur: Does Advocacy Help or Hinder Conflict Resolution?', Praxis 13 (2008), pp. 33-46, 43-4. 